\title{
Comparative cytogenetic analysis of fishes in the genus Trichopodus (Osphronemidae) in Thailand
}

\author{
WEERAYUTH SUPIWONG ${ }^{1}$, PRAYOON WONGCHANTRA ${ }^{2, \boldsymbol{\nu}}$, WEERA THONGNETR ${ }^{3}$, \\ BOONYADA MINGKWAN ${ }^{4}$, PATCHARAPORN CHAIYASAN ${ }^{4}$, SITTHISAK PINMONGKHONKUL $^{5}$, \\ KRIT PINTHONG 6 , ALONGKLOD TANOMTONG ${ }^{4}$ \\ ${ }^{1}$ Applied Science Program, Faculty of Interdisciplinary Studies, Khon Kaen University. Nong Khai Campus, Muang, Nong Khai 43000, Thailand \\ ${ }^{2}$ Faculty of Environment and Resource Studies, Mahasarakham University. Kantharawichai, Maha Sarakham 44150, Thailand. Tel.: +66-816000180, \\ "email: prayoon_nam@yahoo.co.th \\ ${ }^{3}$ Walai Rukhavej Botanical Research Institute, Mahasarakham University. Kantharawichai, Maha Sarakham 44150, Thailand \\ ${ }^{4}$ Department of Biology, Faculty of Science, Khon Kaen University. Muang, Khon Kaen 40002, Thailand \\ ${ }^{5}$ Department of Biology, School of Science, University of Phayao. Muang, Phayao 56000, Thailand \\ ${ }^{6}$ Department of Fundamental Science, Faculty of Science and Technology, Surindra Rajabhat University. Muang, Surin 32000, Thailand
}

Manuscript received: 24 May 2021. Revision accepted: 29 June 2021.

\begin{abstract}
Supiwong W, Wongchantra P, Thongnetr W, Mingkwan B, Chaiyasan P, Pinmongkhonkul S, Pinthong K, Tanomtong A. 2021. Comparative cytogenetic analysis of fishes in the genus Trichopodus (Osphronemidae) in Thailand. Biodiversitas 22: $3029-3036$. Comparative cytogenetic study of four species of the genus Trichopodus including T. leerii, T. microlepis, T. pectoralis, and T. trichopterus from Thailand, was carried out. The specimens were collected from the Basins throughout Thailand. Chromosome preparation was directly performed from the kidney tissues. Conventional staining by Giemsa solution, Ag-NOR banding by silver nitrate solution and $\mathrm{C}$-banding by $\mathrm{NaOH}$ solution were conducted to stain the chromosomes. Results showed that four species studied have the same diploid number and fundamental number as 46 composing of all telocentric chromosomes. Karyotypes consisting of large-medium-small sizes in T. leerii, T. microlepis, T. pectoralis and T. trichopterus were 16-28-2, 14-32-0, 20-26-0 and 10-30-6 chromosomes, respectively. The marker chromosomes which present the NOR positions are the single pair in all species but there are differences in the locations and pairs such as pairs no. 1, 7,2 and 1, respectively. Most species except T. trichopterus, NOR sites locate at interstitial region adjacent to the centromere. T. trichopterus had the telomeric NORs. Constitutive heterochromatin blocks displayed at the centromeric/pericentromeric regions of all chromosomes in T. leerii and T. microlepis whereas in T. pectoralis and T. trichopterus, those presented at not only centromeres of several chromosome pairs, but they also were found at interstitial sites. The obtained finding, cytogenetic data has species-specific. Thus, it can be used for further study on taxonomy. Moreover, this data shows the close relationship of genetics among these species so that the application for breeding may be used in the future.
\end{abstract}

Keywords: Trichopodus, chromosome, karyotype, nucleolar organizer regions, constitutive heterochromatin

\section{INTRODUCTION}

A Trichopodus genus which is formerly included in Trichogaster (Peapke 2009; Töpfer and Schlindler 2009) is tropical freshwater labyrinth fish of the gourami or family Osphronemidae and subfamily Trichogastrinae distributed in Southeast Asia. Gouramis of the genus Trichopodus are closely related to those of Trichogaster (formerly Colisa). Species of both genera have long and thread-like pelvic fins (known as "feelers" in the aquaria trade) used to sense the environment. However, Trichopodus species have shorter dorsal fin base in juvenile stage, when sexually mature, they are much larger (Peapke 2009; Töpfer and Schlindler 2009). There are currently six recognized species in this genus including Trichopodus cantoris, pearl gourami (T. leerii), moonlight gourami (T. microlepis), snakeskin gourami (T. pectoralis), T. poptae and three spot gourami (T. trichopterus) (Peapke 2009). In Thailand, there are only four species recorded in this subfamily and only genus Trichopodus is native species. Three species including T. microlepis, T. pectoralis and T. trichopterus are distributed throughout Thailand while $T$. leerii is native to the To Daeng peat swamp forest, Narathiwat Province, Southern Thailand. These fishes are well-known as economic fish of Thailand. T. trichopterus is popular as fish food species and booming in aquaculture while left three species to have beautiful color as attractive species in a popular ornamental fish (Supiwong et al. 2010). Although the gourami fishes are important for national economy of Thailand, there was quite scarce of cytogenetics in these fishes especially for the banding analysis of their chromosomes. Up to the present, there were ten species in the subfamily Trichogastrinae that have been cytogenetically reported. The diploid chromosome number ( $2 n)$ is 46 or 48 chromosomes and the fundamental number (NF) ranges between 46 and 86 (Table 1). The study on fish chromosomes is the basic knowledge that can be applied for several fields such as classification, evolution, heredity, systematic (Kumar et al. 2014), breeding, rapid production of inbred lines, and cytotaxonomy (Kumar et al. 2014; Abu-Almaaty et al. 2017). Furthermore, cytogenetic studies on fishes also have been used as biological indicators to determine the ecological toxicology (Promsid et al. 2015; Talukdar et al. 2017) and cytogenetic techniques have been 
widely applied to improve farmed stocks in many aquaculture species in the World (Chandra and FroppBayat 2021).

An important characteristic of Nucleolar Organizer Regions (NORs) in fish is related to that it has inter- and intra-species polymorphism. NORs characters are considered as a cytogenetic marker for cytotaxonomic studies and also have been used for studying of phylogenetic relationships among the Cyprinid fishes (Kasiroek et al. 2017; Saenjundaeng et al. 2018a,b; Supiwong et al. 2018). Constitutive heterochromatin distributions on the chromosomes were widely studied in some fish groups (Vicari et al. 2006; Mesquita et al. 2008; Takai 2012). Generally, most constitutive heterochromatins locates at centromeric/pericentromeric regions of the chromosomes. In some cases, these heterochromatins can be revealed at interstitial regions in some Pomacentrid fishes to support that the chromosomal evolution in this family is related to chromosome fusion (Takai 2012). Moreover, constitutive heterochromatins are also highly accumulated on the $\mathrm{W}$ sex chromosome in Parodon hilarii (Parodontidae) (Moreira-Filho et al. 1993,), Characidium fish (Crenuchidae) (Vicari et al. 2008) and Lignobrycon myersi (Triportheidae) (Rodrigues et al. 2016).

As mention above, chromosomal analysis is very important and clearly exhibits the benefits. Moreover, the NORs characteristics and constitutive heterochromatin in almost and all species of the genus Trichopodus, have not been studied. Accordingly, the present study is the first report for comparative cytogenetics in the genus Trichopodus from Thailand by using Ag-NOR banding and C-banding techniques. The knowledge can provide cytogenetic data for supporting the studies of systematics, breeding improvement, and evolutionary relationship in this family.

Table 1. Review of cytogenetic reports of the subfamily Trichogastrinae

\begin{tabular}{|c|c|c|c|c|c|}
\hline Species & $2 n$ & $\mathbf{N F}$ & Karyotype formula & NORs & References \\
\hline \multirow[t]{4}{*}{ Trichogaster chuna } & 46 & 74 & $20 m+8 s m+6 s t+12 a$ & - & Arai (2011) \\
\hline & 46 & 66 & $20 \mathrm{~m}+26 \mathrm{st} / \mathrm{a}$ & - & Arai (2011) \\
\hline & 46 & 86 & $28 m+12 s m+6 a$ & - & Arai (2011) \\
\hline & 46 & 64 & $10 m+8 s m+28 a$ & - & Arai (2011) \\
\hline \multirow[t]{9}{*}{ Trichogaster fasciata } & 48 & 48 & $48 \mathrm{a} / \mathrm{t}$ & - & Arai (2011) \\
\hline & 48 & 74 & $14 \mathrm{~m}+12 \mathrm{sm}+22 \mathrm{a} / \mathrm{t}$ & - & Arai (2011) \\
\hline & 48 & 78 & $8 m+20 s m+12 s t+8 a / t$ & - & Arai (2011) \\
\hline & 48 & 78 & $18 \mathrm{~m}+12 \mathrm{sm}+18 \mathrm{a} / \mathrm{t}$ & - & Arai (2011) \\
\hline & 48 & 68 & $20 m+12 s t+16 a / t$ & - & Arai (2011) \\
\hline & 48 & $80-81$ & $16 m+16 s m+15 a / t(16 a / t)$ & - & Arai (2011) \\
\hline & 48 & 80 & $16 \mathrm{~m}+16 \mathrm{sm}+16 \mathrm{a}$ & - & Arai (2011) \\
\hline & 48 & 83 & $15 \mathrm{~m}+16 \mathrm{sm}+4 \mathrm{st}+13 \mathrm{a} / \mathrm{t}$ & 6 & Arai (2011) \\
\hline & 48 & 86 & $16 \mathrm{~m}+16 \mathrm{sm}+6 \mathrm{st}+10 \mathrm{a} / \mathrm{t}$ & 2 & Arai (2011) \\
\hline \multirow[t]{4}{*}{ Trichogaster labiosa } & 48 & 66 & $12 \mathrm{~m}+6 \mathrm{sm}+12 \mathrm{st}+18 \mathrm{a} / \mathrm{t}$ & - & Arai (2011) \\
\hline & 48 & 82 & $22 \mathrm{~m}+12 \mathrm{sm}+4 \mathrm{st}+12 \mathrm{a}$ & - & Arai (2011) \\
\hline & 48 & 68 & $20 \mathrm{~m}+10 \mathrm{st}+18 \mathrm{a} / \mathrm{t}$ & - & Arai (2011) \\
\hline & 48 & 86 & $22 m+16 s m+10 a$ & - & Arai (2011) \\
\hline \multirow[t]{5}{*}{ Trichogaster lalius } & 46 & 70 & $24 \mathrm{~m} / \mathrm{sm}+22 \mathrm{a} / \mathrm{t}$ & - & Arai (2011) \\
\hline & 46 & - & $26 \mathrm{~m}+1 \mathrm{sm} / \mathrm{st}+19 \mathrm{a} / \mathrm{t}$ & - & Arai (2011) \\
\hline & 46 & 70 & $14 \mathrm{~m}+10 \mathrm{sm}+12 \mathrm{st}+10 \mathrm{a}$ & - & Arai (2011) \\
\hline & 46 & 66 & $20 \mathrm{~m}+8 \mathrm{st}+18 \mathrm{a} / \mathrm{t}$ & - & Arai (2011) \\
\hline & 46 & 66 & $14 m+6 s m+26 a$ & - & Arai (2011) \\
\hline Trichogaster sumatranus & 48 & 48 & $48 s t / a$ & - & Arai (2011) \\
\hline Trichopodus cantoris & 46 & 46 & $46 \mathrm{a} / \mathrm{t}$ & - & Arai (2011) \\
\hline \multirow[t]{4}{*}{ Trichopodus leeri } & 46 & 46 & $46 a / t$ & - & Arai (2011) \\
\hline & 46 & 46 & $46 a / t$ & - & Seetapan and Khamma-Ai (2007) \\
\hline & 46 & 46 & $46 a / t$ & - & Abu-Almaaty et al. (2017) \\
\hline & 46 & 46 & $46 t$ & 2 & Present study \\
\hline \multirow[t]{4}{*}{ Trichopodus microlepis } & 48 & 48 & $48 \mathrm{a} / \mathrm{t}$ & - & Arai (2011) \\
\hline & 46 & 46 & $46 a / t$ & - & Arai (2011) \\
\hline & 46 & 46 & $46 a / t$ & - & Seetapan and Khamma-Ai (2007) \\
\hline & 46 & 46 & $46 t$ & 2 & Present study \\
\hline \multirow[t]{4}{*}{ Trichopodus pectoralis } & 46 & 46 & $46 a / t$ & - & Arai (2011) \\
\hline & 46 & 46 & $46 a / t$ & - & Arai (2011) \\
\hline & 46 & 46 & $46 a / t$ & - & Seetapan and Khamma-Ai (2007) \\
\hline & 46 & 46 & $46 t$ & 2 & Present study \\
\hline \multirow[t]{6}{*}{ Trichopodus trichopterus } & 46 & 46 & $46 a / t$ & - & Arai (2011) \\
\hline & 46 & 46 & $46 a / t$ & - & Arai (2011) \\
\hline & 46 & 46 & $46 a / t$ & - & Arai (2011) \\
\hline & 46 & 46 & $46 \mathrm{t} / \mathrm{t}$ & 2 & Supiwong et al. (2010) \\
\hline & 46 & 46 & $46 a / t$ & - & Abu-Almaaty et al. (2017) \\
\hline & 46 & 46 & $46 t$ & 2 & Present study \\
\hline
\end{tabular}

Note: $2 n$ : diploid chromosome number, NF: fundamental number (number of chromosome arm), m: metacentric, sm: submetacentric, a: acrocentric, t: telocentric, NORs: nucleolar organizer regions, and -: not available 


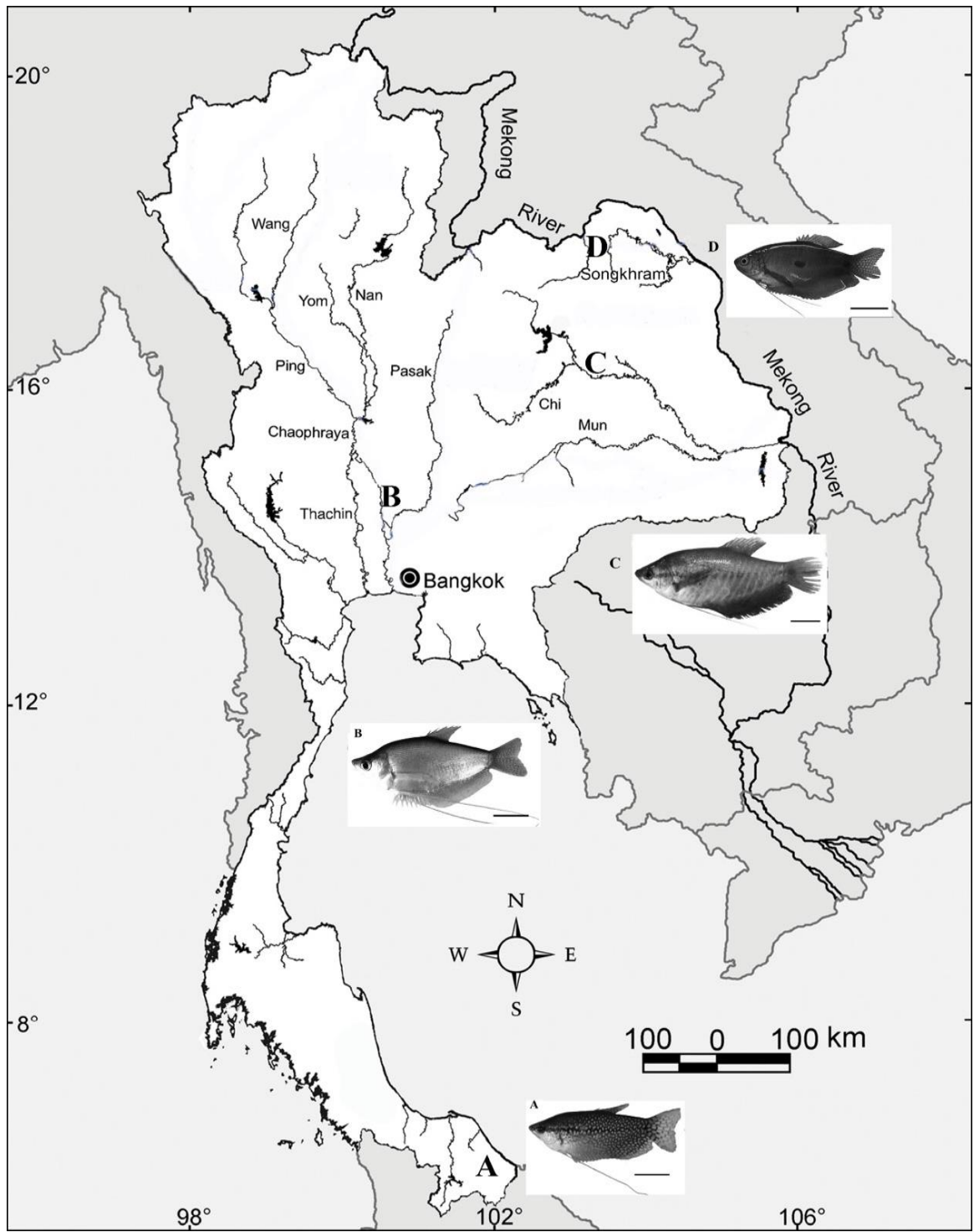

Figure 1. Map showing the sampling sites and characteristics of the Trichopodus specimens: A. T. leeri, B. T. microlepis, C. T. pectoralis, and D. T. trichopterus; scale bars $=2 \mathrm{~cm}$

\section{MATERIALS AND METHODS}

\section{Sample collection}

Ten males and ten females of each species of the Trichopodus were collected from different sites as follows: T. leeri (the To Daeng peat swamp forest, Narathiwat Province), T. microlepis (the Chao Phraya Basin, Sing Buri Province), T. pectoralis (the Chi Basin, Maha Sarakham Province) and T. trichopterus (Nong Khai Province), in Thailand (Figure 1). The fishes were transferred to laboratory aquaria and kept under standard conditions for three days before the experiments. The procedures followed ethical protocols; anesthesia was conducted by kept in freeze before euthanasia, as approved by the Institutional Animal Care and Use Committee of Khon Kaen University, based on the Ethics of Animal Experimentation of the National Research Council of Thailand IACUC-KKU-9/60.

\section{Cytogenetic study}

Chromosomes were directly prepared in vivo (Supiwong et al. 2012a; 2012b; 2013; Ferreira et al. 2021). The chromosomes were then stained by three techniques. Conventional staining technique was carried out by using 20\% Giemsa's solution (Sangpakdee et al. 2015; Sangpakdee et al. 2017; Chaiyasan et al. 2018). Ag-NOR staining was conducted by using $50 \%$ silver nitrate solution (Sreeputhorn et al. 2017; Supiwong et al. 2017; Getlekha and Tanomtong 2020), and C-banding has performed the method of Supiwong et al. (2019). Chromosome counting was performed on mitotic metaphase cells under a light microscope. Twenty cells (from each specimen), clearly observable and well-spread chromosomes were selected and photographed (selected from all specimens). The lengths of short arm (Ls) and long arm (Ll) were measured and the length of total chromosome was calculated (LT, LT $=\mathrm{Ls}+\mathrm{Ll})$. The relative length $(\mathrm{RL})$, the centromeric index 
(CI), and standard deviation (S.D.) of RL and CI were calculated (Phimphan et al. 2013; Pinthong et al. 2017; Juntaree and Supiwong 2020). The CI (q/p) between 0.500$0.599,0.600-0.699,0.700-0.899$, and $0.900-1.000$ were described as metacentric (m), submetacentric (sm), acrocentric (a), and telocentric (t) chromosomes, respectively (Saenjundaeng et al. 2018a,b; Pissaparn et al. 2020; Phimphan et al. 2020). The classify of chromosomal sizes, karyotyping and diagramming methods were followed by Tanomtong et al. (2014), Jantarat et al. (2017), and Chooseangjaew et al. (2017).

\section{RESULTS AND DISCUSSION}

Chromosome number (2n), fundamental number (NF), and karyotype of the Trichopodus

Four studied Trichopodus species have the same diploid number $(2 n)$ and fundamental number (NF) as 46 composing of all telocentric chromosomes (Figure 2). Karyotypes classifying as large-medium-small sizes compose of $16-28-2,14-32-0,20-26-0$ and 10-30-6 chromosomes in T. leerii, T. microlepis, T. pectoralis and T. trichopterus, respectively (Figure 3). The differentiated sizes related to sex chromosomes were not observed. The karyotype formulae for these species are as follows:

T. leerii: $2 n$ (diploid) $46=\mathrm{L}_{16}{ }_{16}+\mathrm{M}_{28}^{\mathrm{t}}+\mathrm{S}_{2}{ }_{2}$ or $2 n$ (diploid) $46=46 \mathrm{t}$

T. microlepis: $2 n$ (diploid) $46=\mathrm{L}^{\mathrm{t}}{ }_{14}+\mathrm{M}^{\mathrm{t}} 32$ or $2 n$ (diploid) $46=46 \mathrm{t}$

T. pectoralis: $2 n$ (diploid) $46=\mathrm{L}_{20}^{\mathrm{t}}+\mathrm{M}_{26}^{\mathrm{t}}$ or $2 n$ (diploid) $46=46 \mathrm{t}$

T. trichopterus: $2 n$ (diploid) $46=\mathrm{L}_{10}^{\mathrm{t}}+\mathrm{M}_{30}^{\mathrm{t}}+\mathrm{S}_{6}^{\mathrm{t}}$ or $2 n$ (diploid) $46=46 \mathrm{t}$

\section{Chromosome markers of the Trichopodus}

The determination of chromosomal markers for all studied species except $T$. trichopterus, was firstly obtained in the present study by using the Ag-NOR staining technique. The marker chromosomes which present the NOR positions are the single pair in all species but there are differences in the locations and pairs such as pairs no. 1, 7, 2 and 1 in T. leerii, T. microlepis, T. pectoralis and T. trichopterus, respectively. NOR sites locate at interstitial region adjacent to the centromere of the chromosomes (interstitial NOR) in three species whereas in $T$. trichopterus, those located at the region adjacent to telomeric position of long arm (telomeric NOR) (Figures 2 and 3).

A ถิ

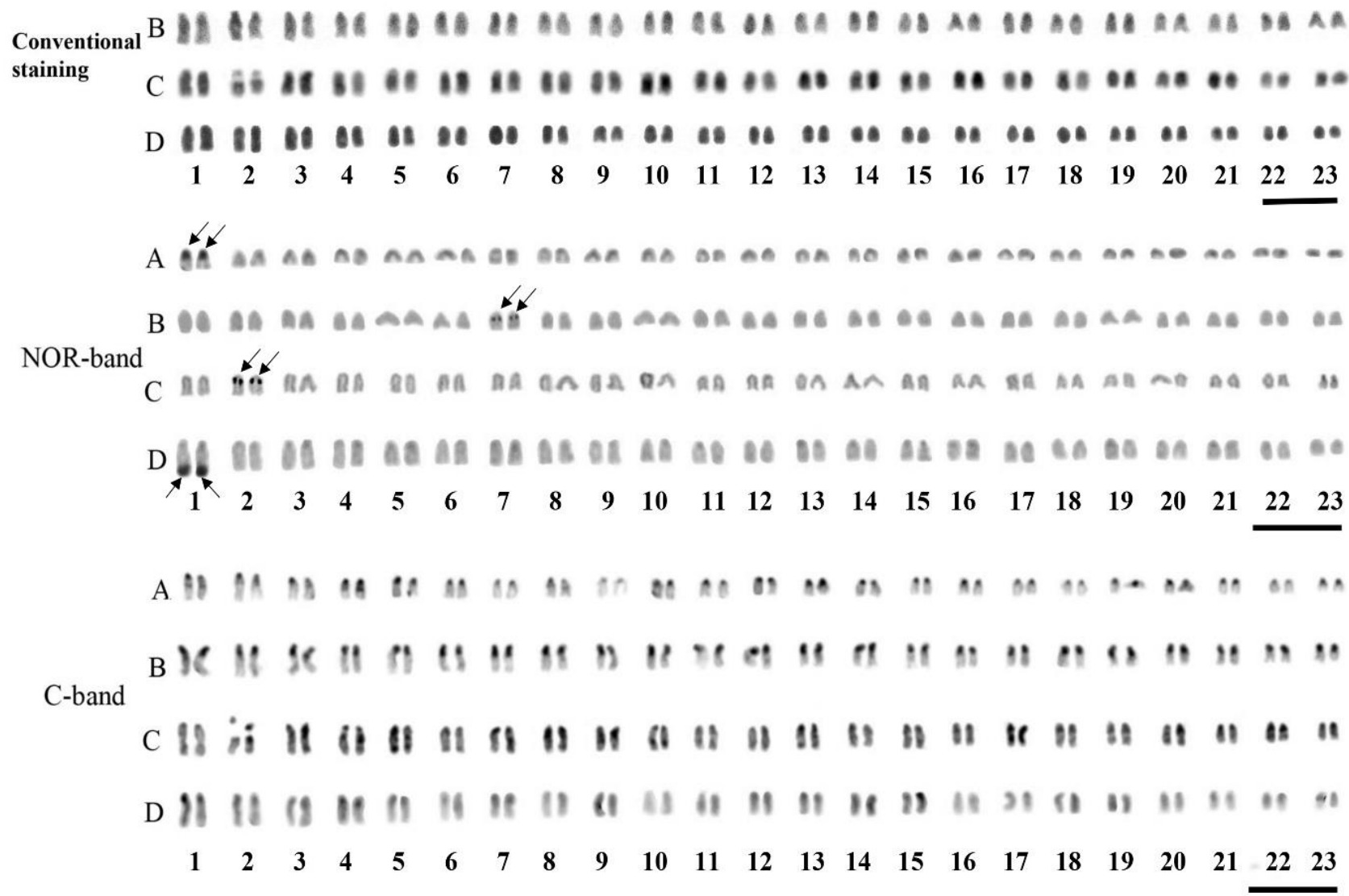

Figure 2. Karyotypes of four Trichopodus, $2 n=46$ by conventional staining, Ag-NOR banding and C-banding techniques; A. T. leeri, B. T. microlepis, C. T. pectoralis and D. T. trichopterus; arrows indicate nucleolar organizer region/NOR. Scale bars. $5 \mu \mathrm{m}$ 

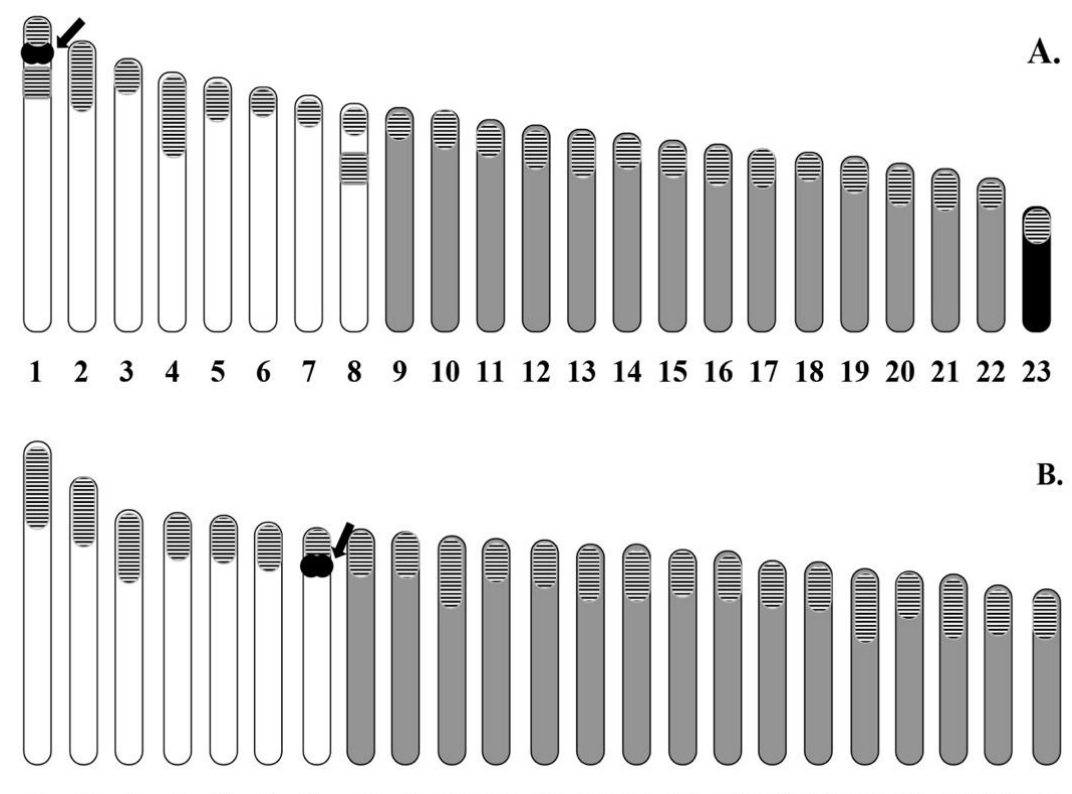

$\begin{array}{lllllllllllllllllllllll}1 & 2 & 3 & 4 & 5 & 6 & 7 & 8 & 9 & 10 & 11 & 12 & 13 & 14 & 15 & 16 & 17 & 18 & 19 & 20 & 21 & 22 & 23\end{array}$

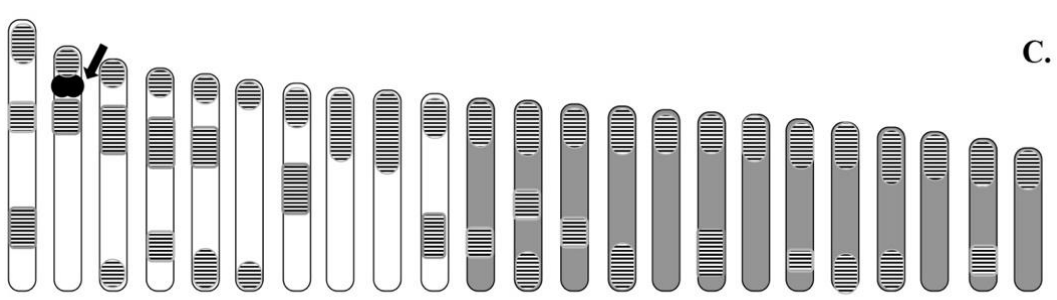

$\begin{array}{lllllllllllllllllllllllll}1 & 2 & 3 & 4 & 5 & 6 & 7 & 8 & 9 & 10 & 11 & 12 & 13 & 14 & 15 & 16 & 17 & 18 & 19 & 20 & 21 & 22 & 23\end{array}$

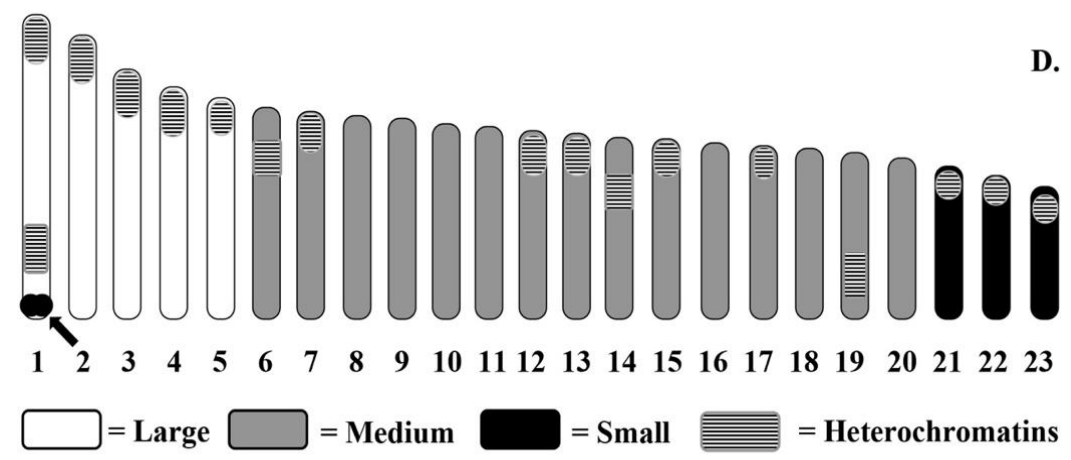

Figure 3. Idiograms showing lengths and shapes of chromosomes of the Trichopodus, $2 n=46$; A. T. leeri, B. T. microlepis, C. T. pectoralis and D. T. trichopterus; arrows indicate nucleolar organizer regions/NORs.

\section{Patterns of constitutive heterochromatin on the chromosomes of the Trichopodus}

The determination of constitutive heterochromatin on chromosomes for all studied species, was firstly analyzed in the present study by using the $\mathrm{C}$-banding technique. Constitutive heterochromatin blocks displayed at the centromeric/pericentromeric regions of all chromosomes in T. leerii, T. microlepis, and T. pectoralis whereas in $T$. trichopterus, those presented at not only centromeres of several chromosome pairs (except pairs 8-11, 14, 16, 18-
20), but they also were found at interstitial sites in the chromosome pairs 1, 6, 14 and 19. However, in T. leerii, constitutive heterochromatin blocks were revealed at interstitial sites near the centromeric regions of the chromosome pairs 1 and 8 while in $T$. pectoralis, those were also observed at telomeric positions of the chromosome pairs 3, 5, 6, 12, 14, 19 and 20, and interstitial sites of the chromosome pairs 1-5, 7, 110-13, 16, 18 and 22 (Figures 2 and 3). 


\section{Discussion}

Chromosome number (2n), fundamental number $(N F)$, and karyotypes of the Trichopodus

The diploid chromosome number $(2 n)$ of all Trichopodus studied was found as 46 chromosomes (Figures 2 and 3). This result is coincident with previous reports (Supiwong et al. 2010; Abu-Almaaty et al. 2017). Moreover, this character is also the same as found in Trichopodus cantoris, Trichogaster chuna and Trichogaster lalius (Arai 2011). These species have the diploid chromosome number of $2 n=46$, which is an apparent modal diploid number of the Trichopodus. Accordingly, it can be concluded that diploid chromosome number in this genus is conserved. However, it differs from T. microlepis reported by Seetapan and Khamma-Ai (2007) and Arai (2011), the most species of the genus Trichogaster (T. labiosa, T. fasciata, T. labiosus, T. sumatranus) which had 2n=48 (Arai 2011) (Table 1).

The fundamental number (NF) of all Trichopodus was 46 in both male and female specimens. The karyotypes consisted of 46 telocentric chromosomes (all as mono-arm chromosomes). These results are agreeable with the previous reports of all Trichopodus species (Magtoon et al. 2007; Seetapan and Khamma-Ai 2007; Supiwong et al. 2010; Arai 2011; Abu-Almaaty et al. 2017). However, they are different from all of the genus Trichogaster (Arai 2011). The NFs of the genus Trichogaster range from 48 to 86 and karyotypes composed of both mono- and bi-arms chromosomes. Nirchio et al. (2002) proposed that species with high NF is advanced state or apomorphic character whereas one with low NF is a primitive state or plesiomorphic character. Thus, the Tricoprodus seems to be a primitive karyotype than Trichogaster. Although four Trichopodus studied have $2 n, \mathrm{NF}$ and the type of chromosome, there are differences in the number of chromosome sizes in karyotypes such as T. leerii and $T$. trichopterus had three sizes of chromosomes as large, medium and small while $T$. microlepis and $T$. pectoralis had only two sizes including large and medium. Thus, karyotype formulae have differences among these species. Moreover, there is no evidence of heteromorphic sex chromosomes in these species which according to all species of this genus (Magtoon et al. 2007; Seetapan and Khamma-Ai 2007; Supiwong et al. 2010; Arai 2011; AbuAlmaaty et al. 2017). Similar to several gourami fishes, no cytologically distinguishable sex chromosomes were distinguished. However, the ZZ/Z0 and XX/X0 sex chromosome systems were revealed in Trichogaster lalius while $\mathrm{ZZ/} \mathrm{ZW} \mathrm{sex} \mathrm{chromosome} \mathrm{system} \mathrm{was} \mathrm{observed} \mathrm{in}$ Trichogaster fasciata (Arai 2011) and Belontia hasselti (Chaiyasan et al. 2021).

\section{Chromosome markers of the Trichopodus}

Present study was firstly accomplished by using AgNOR staining in all species analyzed except $T$. trichopterus. The NORs are used as markers to detect species-specific character and indicate intra- and interspecies chromosomal polymorphism in many groups of fishes (Cioffi et at. 2015; Phimphan et al. 2015; Sarasan et al. 2018; Kasiroek et al. 2017; Yeesin et al. 2021). The Ag-
NOR positions were shown on the single chromosome pair. They are the same as in $T$. trichopterus (Supiwong et al. 2010) and T. fasciata reported by Arai (2011) but there is difference in $T$. fasciata which had three pairs of NORs (Arai 2011) and Betta splendens which had two pairs of NORs (Furgala-Selezniow et al. 2008). Gold and Amemiya (1986) suggested that the occurrence of multiple NORs in fishes was considered to be apomorphic or advance condition whereas single pair of NORs was considered to be plesiomorphic or a primitive condition (Kumar et al. 2013). Considering for NOR loci among four species of this genus in present and previous studies, although all species had a single NOR pair, the NOR positions are different. The present results revealed that $T$. leerii, T. microlepis, and T. pectoralis had interstitial NORs closely to centromeres on the chromosome pairs 1,7 , and 2 , respectively, whereas $T$. trichopterus had telomeric NORs (region adjacent to the telomere) on the chromosome pair 2 (Supiwong et al. 2010) or the chromosome pair 1 (present study). Gornung (2013) suggested that in fishes, the location of NORs in a terminal position, and close to the centromere, is also considered to be a primitive feature as found in T. leerii, T. microlepis, and T. pectoralis. Thus, $T$. trichopterus seems to be part of advance trait due to its NOR position. The chromosomal evolution from ancestor in $T$. trichopterus, has been occurred through pericentric inversion process in NOR-bearing chromosomes. This may be the reason for the description of NOR loci difference between T. trichopterus and other Trichopodus. Therefore, the NOR-bearing chromosome markers can be used as a tool for classification in this fish group. A single NOR pair is considered as a primitive state in fish group. Single NORs are also widespread in several fish taxa (Khakhong et al. 2014; Sochorová et al. 2018).

\section{Patterns of constitutive heterochromatins on the chromosomes of the Trichopodus}

The present study is the first report of the constitutive heterochromatin distributions on the chromosomes in the genus Trichopodus using C-banding. There are various patterns among four species. The constitutive heterochromatic blocks were observed at centromeric and pericentromeric regions of all chromosomes and with no clear interstitial and telomeric positive C-bands in T. leerii and T. microlepis while those were found at all centromeric/ pericentromeric, several telomeric/ peritelomeric and interstitial regions in $T$. pectoralis. Moreover, in $T$. trichopterus, both centromeric/pericentromeric and interstitial regions of several chromosome pairs shown the positive C-bands. It indicates that the chromosomes of $T$. leerii and T. microlepis are conserved and non-related to chromosomal fusion or an increase in heterochromatin during evolution. This result is similar to some species in another family of the order Perciformes such as Geophagus brasiliensis and $C$. facetum in the Cichlidae family (Vicari et al. 2006), Plectroglyphidodon lacrymatus, Chrysiptera leucopoma, C. rex, and Neoglyphidodon melas in the Pomacentridae family (Takai 2012). However, it seems to be that there was chromosomal fusion or an increase in heterochromatin during evolution in $T$. pectoralis and $T$. 
trichopterus. This may be similar to several species which presented the complex types of positive C-bands, e.g., Symphysodon haraldi, S. aequifasciatus, $S$. discus (Cichlidae) having heterochromatic blocks on the pericentromeric regions of all chromosomes and the proximal regions of both arms of some chromosomes (Mesquita et al. 2008), N. nigroris (Pomacentridae) exhibiting the distribution of $\mathrm{C}$-bands in most centromeric regions and including many terminals and interstitial regions (Takai 2012). The idiogram shows a continuous length gradation of chromosomes. The size differences between the largest and smallest chromosomes show approximately two-fold. Idiograms by conventional staining, Ag-NOR banding, and C-banding are shown in Figure 3. They also indicate the differences of NOR mashed chromosomes and constitutive heterochromatin patterns on the chromosomes among the genus Trichopodus.

In conclusion, NOR phenotype and constitutive heterochromatin patterns on the chromosomes are specific to species in the genus Trichopodus. For more information about the chromosomal diversity and chromosomal evolution in this genus, more techniques such as molecular cytogenetic should be further studied.

\section{ACKNOWLEDGEMENTS}

Present work was supported by Mahasarakham University; Research and Technology Transfer Affairs, Khon Kaen University (KKU-NKC60-009); the Research Grant of Khon Kaen University through National Research Council of Thailand (Grant no. 6100015); and Unit of Excellence for water management research (FF64UoE006), University of Phayao, Thailand.

\section{REFERENCES}

Abu-Almaaty AH, Hassan MK, Bahgat IM, Suleiman MEE. 2017. Inter simple sequence repeat (ISSR) and cytogenetic analysis of three fish species of family Osphronemidae. Egypt J Aquat Biol Fish 21 (2): 115. DOI: 10.21608/ejabf.2017.2436.

Arai R. 2011. Fish Karyotypes: A Checklist. Springer, Tokyo.

Chaiyasan P, Supiwong W, Saenjundaeng P, Seetapan K, Pinmongkhonkul S, Tanomtong A. 2018. A report on classical cytogenetics of high fin Barb fish, Cyclocheilichthys armatus (Cypriniformes, Cyprinidae). Cytologia 83 (2): 149-154. DOI: 10.1508/CYTOLOGIA.83.149.

Chaiyasan P, Mingkwan B, Jantarat S, Suwannapoom C, Cioffi MB, Liehr T, Talumphai S, Tanomtong A, Supiwong W. 2021. Classical and molecular cytogenetics of Belontia hasselti (Perciformes: Osphronemidae): Insights into the ZZ/ZW sex chromosome system. Biodiversitas 22 (2): 548-556. DOI: 10.13057/biodiv/d220205.

Chandra G, Fopp-Bayat D. 2021. Trends in aquaculture and conservation of sturgeons: A review of molecular and cytogenetic tools. Rev Aquacult 13: 119-137. DOI: 10.1111/raq.12466.

Chooseangjaew S, Tanyaros S, Maneechot N, Buasriyot P, Getlekha N, Tanomtong A. 2017. Chromosomal characteristics of the tropical oyster, Crassostrea belcheri Sowerby, 1871 (Ostreoida, Ostreidae) by conventional and Ag-NOR banding techniques. Cytologia 82: 3-8. DOI: $10.1508 /$ cytologia.82.3.

Cioffi MB, Bertollo LAC, Villa MA, Oliveira EA, Tanomtong A, Yano CF, Supiwong W, Chaveerach A. 2015. Genomic organization of repetitive DNA elements and its implications for the chromosomal evolution of channid fishes (Actinopterygii, Perciformes). PLoS One 10 (6): e0130199. DOI: 10.1371/journal.pone.0130199.

Ferreira AMV, Viana PF, Zuanon J, Ezaz T, Cioffi MB, Takagui FH, Feldberg E. 2021. Cytogenetic Analysis of Panaqolus tankei Cramer and Sousa, 2016 (Siluriformes, Loricariidae), an ornamental fish endemic to Xingu River, Brazil. Cytogenet Genome Res. DOI: $10.1159 / 000514061$.

Getlekha N, Tanomtong A. 2020. First cytogenetic study of green chromis, Chromis viridis (Perciformes, Pomacentridae) by conventional staining and Ag-NOR banding techniques. Chiang Mai Univ J Nat Sci 19 (2): 164-175. DOI: 10.12982/CMUJNS.2020.0011.

Gornung E. 2013. Twenty years of physical mapping of major ribosomal RNA genes across the Teleosts: A review of research. Cytogenet Genome Res 141 (2-3): 90-102. DOI: 10.1159/000354832

Jantarat S, Supiwong W, Phintong K, Sonsrin K, Kong-ngarm N, Tanomtong A. 2017. First analysis on the cytogenetics of painted sweetlips, Plectorhinchus pictus (Heamulidae: Perciformes) from Thailand. Cytologia 82 (2): 145-150. DOI: 10.1508/cytologia.73.145.

Juntaree S, Supiwong W. 2020. Standardized karyotype and idiogram of the glass goby fish (Gobiopterus chuno) (Hamilton, 1822) in Thailand. Sci Technol Engineer J 6 (2): 72-81.

Kasiroek W, Indananda C, Pinthong K, Supiwong W, Pengseng P, Tanomtong A. 2017. NOR polymorphism and chromosome analysis of Banggai cardinalfish, Pterapogon kauderni (Perciformes, Apogonidae). Cytologia 82 (1): 17-23. DOI: 10.1508/cytologia.82.17

Kumar R, Kushwaha B, Nagpure NS, Behera BK, Lakra WS. 2013. Karyological and molecular diversity in three freshwater species of the genus Channa (Teleostei, Perciformes) from India. Caryologia 66 (2): 109-119. DOI: 10.1080/00087114.2013.821829.

Kumar R, Sahoo PK, Vishwanath W, Barat A. 2014. Karyotype of a new loach Schistura obliquofascia and a mahseer Puntius chelynoides from Kumaun Hills of Himalaya. Cytologia 79 (2): 243-246. DOI: 10.1508/cytologia.79.243.

Khakhong S, Supiwong W, Tanomtong A, Sriuttha M, Jearranaiprepame P, Soemphol W, Jiwyam W. 2014. A first chromosomal characterization of NORs in splendid snakehead fish, Channa lucius (Perciformes, Channidae). Cytologia 79 (2): 133-139. DOI: 10.1508/cytologia.79.133.

Magtoon W, Rangsiruji A, Donsakul T. 2007. Karyotypes of Betta splendens, B. rima, Trichopsis vittatus and Trichogaster trichopterus (family Belontiidae) from Thailand. In: The 33rd Congress on Science and Technology of Thailand. Nakhon Sri Thammarat, Thailand.

Mesquita DR, Porto JIR, Feldberg E. 2008. Chromosomal variability in the wild ornamental species of Symphysodon (Perciformes: Cichlidae) from Amazon. Neotrop Ichthyol 6 (2): 181-190. DOI: 10.1590/S1679-62252008000200005.

Moreira-Filho O, Bertollo LAC, Galetti Jr. PM 1993. Distribution of sex chromosome mechanisms in neotropical fish and description of a ZZ/ZW system in Parodon hilarii (Parodontidae). Caryologia 46: 115125. DOI: 10.1080/00087114.1993.10797253.

Nirchio M, Turner BJ, Perez JE, Gaviria JI, Cequea H. 2002. Karyotypes of three species of toadfish (Batrachoididae: Teleostei) from Venezuela. Scientia Marina 66 (1): 1-4. DOI: 10.3989/scimar.2002.66n11.

Peapke HJ. 2009. The nomenclature of Trichopodus pectoralis Regan, 1910; Trichopodus cantoris Sauvage, 1884 and Osphronemus saigonensis Borodin, 1930 (Teleostei: Perciformes: Osphronemidae). Vertebrate Zool 59 (1): 53-60.

Pissaparn M, Phimphan S, Chaiyasan P, Tanoamtong A, Liehr T, Suwannapoom C, Reungsing M, Supiwong W. 2020. First chromosome analysis of Thai pufferfish Pao cochinchinensis (Steindachner, 1866). Biodiversitas 21: 4309-4316. DOI: 10.13057/biodiv/d210949.

Phimphan S, Tanomtong A, Jumrusthanasan S, Supiwong W, Siripiyasing P, Sanoamuang L. 2013. First Report of NOR polymorphism and chromosome analysis of John's Snapper, Lutjanus johnii (Perciformes, Lutjanidae) in Thailand. Cytologia 78 (4): 335-344. DOI: 10.1508/cytologia.78.335.

Phimphan S, Tanomtong A, Supiwong W, Nithikulworawong N, Suvarnaraksha A, Kaewsri S. 2015. Karyological analysis of the barramundi, Lates calcarifer (Perciformes, Latidae). Cytologia 80 (2): 167-172. DOI: 10.1508/cytologia.80.167.

Phimphan S, Chaiyasan P, Suwannapoom C, Reungsing M, Juntaree S, Tanomtong A, Supiwong W. 2020. Comparative karyotype study of three Cyprinids (Cyprinidae, Cyprininae) in Thailand by classical 
cytogenetic and FISH techniques. Comp Cytogen 14 (4): 597-612. DOI: 10.3897/CompCytogen.v14i4.54428.

Pinthong K, Supiwong W, Simporn B, Chooseangjaew S, Kakampuy W, Tanomtong A. 2017. A first chromosomal and nucleolar organizer regions (NORs) analyses of Cheveys sheatfish, Micronema cheveyi (Siluriformes, Siluridae). Cytologia 82 (4): 435-441. DOI: 10.1508/cytologia.82.435.

Promsid P, Neeratanaphan L, Supiwong W, Sriuttha M, Tanomtong A 2015. Chromosomal aberration of snakehead fish (Channa striata) in affected reservoir by leachate with lead and mercury contamination. Int J Environ Res 9 (3): 897-906.

Rodrigues AS, Medrado AS, Diniz C, Oliveira PR, Affonso AM. 2016. ZZ/ZW sex chromosome system in the endangered fish Lignobrycon myersi Miranda-Ribeiro, 1956 (Teleostei, Characiformes, Triportheidae). Comp Cytogenet 10 (2): 245-254. DOI: 10.3897/CompCytogen.v10i2.8435.

Saenjundaeng P, Kaewmad P, Supiwong W, Pinthong K, Pengseng P, Tanomtong A. 2018. Karyotype and characteristics of nucleolar organizer regions in longfin carp, Labiobarbus leptocheilus (Cypriniformes, Cyprinidae). Cytologia 83 (3): 265-269. DOI: 10.1508/cytologia.83.265.

Saenjundaeng P, Cioffi MB, Oliveira EA, Tanomtong A, Supiwong W, Phimphan S, Collares-Pereira MJ, Sember A, Bertollo LAC, Liehr T, Yano CF, Hatanaka T, Ráb T. 2018. Chromosomes of Asian cyprinid fishes: Cytogenetic analysis of two representatives of small paleotetraploid tribe Probarbini. Mol Cytogenet 11 (51): 1-9. DOI: 10.1186/s13039-018-0399-8.

Sangpakdee W, Phimphan S, Tanomtong A, Patawang I, Pinthong K, Neeratanaphan L. 2015. Karyological study of Lutjanus ehrenbergii and $L$. carponotatus (Perciformes, Lutjanidae) by classical and $\mathrm{Ag}$ NOR staining techniques. Nucleus (India) 58 (3): 1-7. DOI: 10.1007/s13237-015-0150-3.

Sangpakdee W, Phimphan S, Tengjaroenkul B, Pinthong K, Neeratanaphan L, Tanomtong A. 2017. Cytogenetic study of three microhylid species (Anura, Microhylidae) from Thailand. Cytologia 82: 67-74. DOI: 10.1508/cytologia.82.67.

Sarasan T, Jantarat S, Supiwong We, Yeesin P, Srisamoot N, Tanomtong A. 2018. Chromosomal analysis of two snakehead fishes, Channa marulius (Hamilton, 1822) and C. marulioides (Bleeker, 1851) (Perciformes: Channidae) in Thailand. Cytologia 83 (1): 115-121. DOI: $10.1508 /$ cytologia.83.115.

Seetapan K, Khamma-Ai M. 2007. Karyotypes of the genus Trichogaster from Thailand. In: The Proceedings of Fisheries Annual Conference. Bangkok, Thailand.

Sochorová J, Garcia S, Gálvez F, Symonová R, Kovaří A. 2018. Evolutionary trends in animal ribosomal DNA loci: Introduction to a new online database. Chromosoma 127 (1): 141-150. DOI: 10.1007/s00412-017-0651-8.

Sreeputhorn K, Mangumphan K, Muanphet B, Tanomtong A, Supiwong W, Kaewmad P. 2017. The First report on chromosome analysis of F1 Hybrid catfish: Mekong giant catfish (Pangasianodon gigas) xstriped catfish (Pangasianodon hypophthalmus) and spot pangasius (Pangasius larnaudii) $\times$ Pangasianodon hypophthalmus (Siluriformes, Pangasiidae). Cytologia 82 (4): 457-463. DOI: 10.1508/cytologia.82.457.

Supiwong W, Tanomtong A, Chaveerach A, Tanee T, Khakhong S, Sanoamuang L. 2013. Interpopulational variation of NOR positions and karyotypic analysis of Siamese catfish (Pseudomystus siamensis) in Thailand. Cytologia 78 (1): 25-34. DOI: 10.1508 /cytologia.78.25.

Supiwong W, Tanomtong A, Kenthao A, Seetapan K, Kaewsri S. 2010. Standardized karyotype and ideogram of the three-spot gourami,
Trichogaster trichopterus (Perciformes, Belontidae) from Thailand by conventional staining and Ag-NOR staining techniques. Nucleus 53 (3): 103-107. DOI: 10.1007/s13237-011-0016-2.

Supiwong W, Tanomtong A, Supanuam P, Jantarat S, Khakhong S, Sanoamuang S. 2012a. A discovery of nucleolar organizer regions (NORs) polymorphism and karyological analysis of Smith's barb, Puntioplites proctozysron (Cypriniformes, Cyprinidae) in Thailand. Cytologia 77 (1): 35-42. DOI: 10.1508/cytologia.77.35.

Supiwong W, Tanomtong A, Jumrusthanasan S, Khakhong S, Leelarasamee K, Sanoamuang L. 2012b. A first karyotype analysis and chromosomal characteristic of nucleolar organizer regions (NORs) of common sheathfish, Micronema apogon (Siluriformes, Siluridae) in Thailand. Cytologia 77 (1): 53-58. DOI: 10.1508/cytologia.77.53.

Supiwong W, Phimphan S, Kaewmad P, Saenjundaeng P, Jantarat S, Tanomtong A. 2017. First cytogenetic study of the white cheek monocle bream, Scolopsis vosmeri (Perciformes, Nemipteridae) from Thailand. Cytologia 82 (5): 481-484. DOI: 10.1508/cytologia.82.481.

Supiwong W, Getlakha N, Chaiphech S, Pinthong K, Phimphan S, Tanomtong A. 2018. Nucleolar organizer regions polymorphism and karyological analysis of black lancer, Bagrichthys majusculus (Siluriformes, Bagridae) in Thailand. Cytologia 83 (2): 193-199. DOI: 10.1508 /cytologia.83.193.

Supiwong W, Pinthong K, Seetapan K, Saenjundaeng P, Bertollo LAC, Oliveira EA, Yano CF, Liehr T, Phimphan S, Tanomtong A, Cioffi MB. 2019. Karyotype diversity and evolutionary trends in the Asian swamp eel Monopterus albus (Synbranchiformes, Synbranchidae): A case of chromosomal speciation?. BMC Evol Biol 19: 73. DOI: $10.1186 / \mathrm{s} 12862-019-1393-4$.

Takai A. 2012. Chromosomal distribution of C-band-positive heterochromatin in eight species of Pomacentridae (Perciformes). Chromosome Sci 15 (1-2): 39-42.

Talukdar B, Kalita HK, Basumatary S, Saikia DJ, Sarma D. 2017. Cytotoxic and genotoxic affects of acid mine drainage on fish Channa punctata (Bloch). Ecotoxicol Environ Saf 144: 72-78. DOI: 10.1016/j.ecoenv.2017.06.007.

Tanomtong A, Supiwong W, Jearranaiprepame P, Khakhong S, Kongpironchuen C, Getlekha N. 2014. A new natural autotetraploid and chromosomal characteristics of dwarf snakehead fish, Channa gachua (Perciformes, Channidae) in Thailand. Cytologia 79 (1): 15-27. DOI: 10.1508/cytologia.79.15.

Töpfer J, Schlindler I. 2009. On the type species of Trichopodus (Teleostei: Perciformes: Osphronemidae). Vertebrate Zool 59 (1): 4951

Vicari MR, Artoni RF, Moreira-Filho O, Bertollo LAC. 2006. Basic and molecular cytogenetics in freshwater Cichlidae (Osteichthyes, Perciformes). Karyotypic conservationism and divergence. Caryologia 59 (3): 260-266. DOI: 10.1080/00087114.2006.10797924.

Vicari MR, Artoni RF, Moreira-Filho O, Bertollo LAC. 2008. Diversification of a ZZ/ZW sex chromosome system in Characidium fish (Crenuchidae, Characiformes). Genetica 134 (3): 311-317. DOI: 10.1007/s10709-007-9238-2.

Yeesin P, Buasriyot P, Ditcharoen S, Chaiyasan P, Suwannapoom C, Juntaree S, Jantarat S, Talumphai S, Cioffi MB, Liehr T, Tanomtong A, Supiwong W. 2021. Comparative study of four Mystus species (Bagridae, Siluriformes) from Thailand: Insights into their karyotypic $\begin{array}{lllll}\text { diversity. Comp Cytogenet } 15 & \text { (2): 119-136. DOI: }\end{array}$ 10.3897/CompCytogen.v15i2.60649. 